Journal of the Rubber Research Institute of Sri Lanka, (2007) 88, 30-46

\title{
Cinnamon (Cinnamomum verum J. Pres) intercropped under different inter row spacings of rubber (Hevea brasiliensis Muell. Arg.): Performance after rubber reached maturity
}

\author{
L. S S Pathiratna*, M K P Perera** and C K Balasooriya**
}

Received 01 December 2006; Accepted 22 January 2007

\begin{abstract}
Performance of cinnamon as an intercrop under rubber planted with different inter row spacings ranging from $7.2 \mathrm{~m}-18.0 \mathrm{~m}$ was investigated for eight years. Cinnamon was first harvested in the third year and the data for the first five years showed the insufficiency of narrow inter row spacings for intercropping cinnamon due to competition from rubber both above and below ground particularly in the third harvest taken in the $5^{\text {th }}$ year. The advantage of wider inter row spacings particularly those above $15.6 \mathrm{~m}$ with paired rows of rubber was evident resulting in higher yields of cinnamon. Reduction of the pay back period in the rubber/ cinnamon systems particularly under wider inter row spacings were also seen as a major advantage. The shade and below ground competition seems to be severe in the narrow spacing treatments with $7.2 \mathrm{~m}-10.8 \mathrm{~m}$ single row after the $6^{\text {th }}$ year and the values of all yield components of cinnamon were reduced resulting in the lowering of cinnamon bark yields and is clearly seen in the $6^{\text {th }}$ harvest taken in the $8^{\text {th }}$ year after establishment. Under wider inter row spacings of rubber between $15.6 \mathrm{~m}-18.0 \mathrm{~m}$ higher bark yields were maintained throughout. The growth and grams/tree/tapping yield of rubber was highest in treatments with lowest tree densities and was decided by the tree density and not by spacing. Having cinnamon as the inter crop clearly showed an advantage on the growth and yield of rubber. There was a cumulative net gain income of rubber cinnamon systems under all spacing treatments and the net gains were in the range of Rs.400,000-450,000 in $12.0 \mathrm{~m}, 13.2 \mathrm{~m}$ single row and $15.6 \mathrm{~m}, 16.8 \mathrm{~m}$ and $18.0 \mathrm{~m}$ paired row systems with rubber at the end of the $8^{\text {th }}$ year of establishment. Performance of cinnamon under wider inter row spacings can be expected to remain as further increases in the size of the rubber canopy is not envisaged. The beneficial effect of having cinnamon as the intercrop on the growth and yield of rubber and the use of wider inter row spacings for intercropping cinnamon to obtain high economic gains is clearly evident in these data collected during the eight year period.
\end{abstract}

Key words: Cinnamomum verum, competition, Hevea brasiliensis, intercropping, light availability, yield, yield components

* Kurunduwatta Centre Road, Nagoda, Kalutara, Sri Lanka

** Rubber Research Institute of Sri Lanka, Dartonfield, Agalawatta, Sri Lanka 


\section{S S Pathiratna et al.}

\section{Introduction}

Growing intercrops under rubber was a practice for many years and research on crops suitable for intercropping has been in progress throughout. Sustainable management of intercrops under conventional inter row spacings of rubber such as $8.1 \mathrm{~m}$ was found to be limited to about 5 years (Pathiratna and Perera 2002; Pathiratna and Perera 2004) due to the expansion of the rubber canopy into the inter row space limiting available light (Pathiratna and Perera $2003 \mathrm{~b}$ ) and also due to the invasion of the rubber roots into the inter row space (Pathrratna and Perera 2003a). Though cinnamon is known to grow and yield satisfactorily under moderate shade (Pathiratna and Perera 1998; Pathiratna et al., 1998; Pathiratna and Perera, 2006) canopy closure and root competition in narrow inter row spacings of rubber were great and the bark yields were greatly reduced (Pathiratna and Perera 2004). In crops where biomass is harvested, the effects on regeneration and growth seem to be severe (Kandiah et al., 1984). Cinnamon was also subjected to the combined effects of shade root competition and defoliation in all rubber/cinnamon intercropping systems.

Cinnamon intercropped under wider inter row spacings of rubber such as $14.4 \mathrm{~m}, 15.6 \mathrm{~m}, 16.8 \mathrm{~m}$ and $18.0 \mathrm{~m}$ have shown to maintain high bark yields even after five years of establishment (Pathiratna et al., 2004). Closure of the rubber canopy and the occupation of the inter row space with rubber roots takes place early in narrow inter row spacings reducing the bark yields (Pathiratna and Perera 2002). The effect of competition from shade and roots of rubber is also severe on cinnamon rows close to the rubber trees. Roots in particular expand its area of coverage with age (Schroth 1999) and competition from the roots of the tree component generally affects the performance of intercrops (Cannell 1983, Conner 1983, van Noordwijk \& Purnomoshidi, 1995). In the $3^{\text {rd }}$ harvest, all yield components of cinnamon (Pathiratna, 2006a) including the total length of harvested sticks, average length/stick and weight of bark $/ \mathrm{cm}^{2}$ were reduced in the narrow inter row spacing treatments but remains without much change in wider inter row spacings. However the average length of a stick seems to remain least affected due to the shade under narrow inter row spacings (Pathitratna et al., 2004) as it is a parameter that is mostly decided by mutual shading rather than over storey shading when shade levels are moderate (Pathiratna and Perera 2006).

Possibilities of making use of wider inter row spacings for intercropping cinnamon were investigated in an experiment where eleven inter row spacings ranging from $7.2 \mathrm{~m} \mathrm{~S}(\mathrm{~S}=$ single rows of rubber $)$, $8.4 \mathrm{~m} \mathrm{~S}, 9.6 \mathrm{~m} \mathrm{~S}, 10.8 \mathrm{~m} \mathrm{~S}, 12.0 \mathrm{~m} \mathrm{~S}, 13.2 \mathrm{~m}$ $\mathrm{S}, 13.2 \mathrm{mP}(\mathrm{P}=$ paired rows of rubber $)$, $14.4 \mathrm{~m} \mathrm{P}, 15.6 \mathrm{~m} P, 16.8 \mathrm{~m}$ and $18.0 \mathrm{~m}, \mathrm{P}$ were tested. The data obtained during the first five years of establishment i.e. when rubber was immature and after three annual harvests of cinnamon was 
Cinnamon intercropping under rubber

published (Pathiratna et al., 2004). The data presented here compiles the results obtained during the next three years after rubber reached maturity.

\section{Materials and Methods}

The experiment was located in the RRISL Sub-Station at Kuruwita in the Ratnapura district. The land is almost flat and the soil type is Red Yellow Podzolic. The annual rainfall was between $3000-4000 \mathrm{~mm}$ and was well distributed during most part of the year.

\section{Experimental design}

The experiment consisted of 11 rubber inter row spacing treatments ranging from $7.2 \mathrm{~m}-18.0 \mathrm{~m}$. The stepwise increase of the inter row space in each treatment was $1.2 \mathrm{~m}$ which is equal to the space between two cinnamon rows. The density of rubber (trees/ha) was low when the inter row spacing was more than $12.0 \mathrm{~m}$ and to rectify this $2.4 \mathrm{~m}$ triangularly spaced paired rows of rubber were included. There was a corresponding increase in the number of cinnamon rows in these treatments and were arranged in a systematic design enabling to accommodate all 11 treatments in a small area (Table 1). Further details are given in Pathiratna et al. (2004) and Pathiratna (2006). As cinnamon was intercropped only in a section of each inter row spacing treatment there was a section under sole rubber and the measurements in this plots were taken and analyzed separately.

Table 1. Spacing and plant densities of rubber and cinnamon in each of inter row spacing treatment with single and paired rows of rubber

\begin{tabular}{ccc}
\hline $\begin{array}{c}\text { Inter row space } \\
(\mathbf{m})\end{array}$ & Rubber trees/ha & $\begin{array}{c}\text { Cinnamon bushes/ } \\
\text { ha }\end{array}$ \\
\hline $\begin{array}{c}\text { Single rows } \\
7.2\end{array}$ & 579 & \\
8.4 & 496 & 9230 \\
9.6 & 434 & 9940 \\
10.8 & 386 & 10435 \\
12.0 & 347 & 10815 \\
13.2 & 331 & 11120 \\
Paired rows & & 11368 \\
13.2 & 545 & \\
14.4 & 505 & 9800 \\
15.6 & 471 & 10100 \\
16.8 & 441 & 10303 \\
18.0 & 415 & 10582 \\
\hline
\end{tabular}




\section{S S Pathiratna et al.}

\section{Fertilizer}

Rubber was fertilized at the rate of $400 \mathrm{~kg} / \mathrm{ha}$. with a 12:14:14: NPK mixture. Fertilizer for cinnamon was a 14:11:14 NPK mixture applied at the rate of $60.0 \mathrm{~g}$ per bush $(480 \mathrm{~kg} / \mathrm{ha})$ and was applied as two split doses. All leaves and twigs of cinnamon that remained after the harvests amounting to about $8000 \mathrm{~kg} / \mathrm{ha} / \mathrm{year}$ were retumed to the same plots.

\section{Measurements}

Cinnamon

Annual harvesting of cinnamon was continued according to the procedures followed earlier (Pathiratna et al., 2004). Mature sticks from three bushes in each row were sampled. The leaves, brown stems and green stems were weighed separately and samples were taken, dried at $70^{\circ} \mathrm{c}$ over-night to determine total above ground biomass. Number of sticks per bush and the total length of mature sticks harvested from each bush were recorded. The mature sticks were peeled and the bark yield was determined. Bark from three $10 \mathrm{~cm}$ portions from the two ends and the middle of every stick was taken, their diameter and weight of bark were recorded to determine the weight of bark per $\mathrm{cm}^{2}$.

\section{Growth and yield of rubber}

Growth of rubber was measured annually as girth at a height of $150 \mathrm{~cm}$ above the graft union. Tapping of rubber was started in the $6^{\text {th }}$ year after establishment and was done on a half spiral alternate daily system ( $1 / 2 \mathrm{~s} \mathrm{~d} 2)$. Latex from each treatment was collected and the volume was measured and a 'Metrolac' reading was taken for estimating the dry rubber content of rubber. The number of trees in tapping and the total number in each treatment was counted for estimating the grams/tree/tapping $(g / t / t)$. Eight and six such measurements per year were taken in the first and second years of tapping respectively.

Light availability in the inter row space

Measurement of light availability was made above the cinnamon canopy using a Delta $-T$ Canopy Analysis system connected with a Beam Fraction Sensor (Delta -T Devices Ltd. UK) which enabled to take a measurement of light in an open place with every reading taken. The measurements were in PAR ( $\mu$ mols $\mathrm{m}^{2} \mathrm{~s}^{-1}$ ) and the transmission of light through the canopy was recorded.

Measurements were taken above the cinnamon canopy at two distances i.e. $3.0 \mathrm{~m}$ and in the middle of the inter row parallel to the effective rubber row and three measurements from each distance were taken at $9.00,12.00,14.00 \mathrm{hrs}$ of the day and was repeated for 3 days.

\section{Estimation of the cumulative net revenue}

Discounted cumulative net revenue for the rubber/cinnamon systems under different inter row spacings was calculated for the whole 
period of eight years using the following items. (1) Expenditure on planting rubber, upkeep for the first 5 years and cost of tapping and manufacture of rubber for the next three years, (2) expenditure of planting and upkeep of cinnamon (3) Expenditure of harvesting and processing of cinnamon ( $40 \%$ of the income from cinnamon) (4) Income from cinnamon. Selling price of cinnamon for the first three harvests based on the average price in the local market were taken as Rs.350/ $\mathrm{kg}$ of dried bark and for the next three harvests this was taken as Rs.550/ $\mathrm{kg}$. Cost of tapping and manufacture of rubber was taken as $\mathrm{Rs} .43 / \mathrm{kg}$ and the selling price was taken as $\mathrm{Rs} .145 / \mathrm{kg}$.

\section{Results}

\section{Yield of cinnamon}

Highest cinnamon yield (grams/bush) in the $4^{\text {th }}$ harvest was obtained in the $16.8 \mathrm{~m} \mathrm{P}(\mathrm{P}=$ paired rows of rubber) and $15.6 \mathrm{~m} \mathrm{P}$ treatments. Those with $14.4 \mathrm{~m} \mathrm{P}$ and $18.0 \mathrm{~m} \mathrm{P}$ also gave comparable yields with that of the $15.6 \mathrm{~m} \mathrm{P}$ treatment. Lowest yields were in the $7.2 \mathrm{~m} \mathrm{~S}, 8.4 \mathrm{~m} \mathrm{~S}, 9.6 \mathrm{~m} \mathrm{~S}, 10.8 \mathrm{~m} \mathrm{~S}$ ( $\mathrm{S}=$ single rows of rubber), inter row spacing treatments. In the $5^{\text {th }}$ harvest 13.2- $\mathrm{S}, 15.6 \mathrm{~m} \mathrm{P}, 16.8 \mathrm{~m} \mathrm{P}$ and $18.0 \mathrm{~m} \mathrm{P}$ treatments gave highest and those of $7.2 \mathrm{~m} \mathrm{~S}, 8.4 \mathrm{~m} \mathrm{~S}, 9.6 \mathrm{~m} \mathrm{~S} 10.8 \mathrm{~m} \mathrm{~S}, 12.0 \mathrm{~m}$
$S$ were comparable and significantly lower than the $16.8 \mathrm{~m} \mathrm{P}$ and $18.0 \mathrm{~m} \mathrm{P}$ inter row spacing treatments. In the $6^{\text {th }}$ harvest also the highest yields were obtained in the $13.2 \mathrm{~m} \mathrm{~S}, 15.6 \mathrm{~m} \mathrm{P}$, $16.8 \mathrm{~m} \mathrm{P}$ and $18.0 \mathrm{~m} \mathrm{P}$ paired row treatments. Bark yields of $12.0 \mathrm{~m} \mathrm{~S}$, $13.2 \mathrm{~m} \mathrm{P.} 14.4 \mathrm{~m} \quad P$ and $15.6 \mathrm{~m} \mathrm{P}$ treatments were comparable and those of $7.2 \mathrm{~m}$ and $8.4 \mathrm{~m}$ treatments were lowest. The yields of $13.2 \mathrm{~m}$ single row was significantly higher than those of $13.2 \mathrm{~m} \mathrm{P}$ in the $5^{\text {th }}$ and $6^{\text {th }}$ harvests despite their similarity in the inter row space but with different rubber tree densities (Table 2).

Increases in the $\mathrm{kg} / \mathrm{ha}$ yield of cinnamon with the increase in the inter row space in both single and paired rows were seen. $\mathrm{kg} / \mathrm{ha}$ yield of cinnamon was highest in the wider inter row spacing treatments ranging from $15.6 \mathrm{~m} \mathrm{P}-18.0 \mathrm{~m} \mathrm{P}$ in all three harvests and was low in narrow inter row spacing treatments. There was a considerable reduction in the $\mathrm{kg} / \mathrm{ha}$ yields at the third harvest in the first two narrow inter row spacing treatments while the wider inter row spacing treatments did not show such reduction in $\mathrm{kg} /$ ha yield. High yields shown by the $13.2 \mathrm{~m} \mathrm{~S}$ compared to the $13.2 \mathrm{~m} \mathrm{P}$ treatment were common to all three harvests (Table 3 ). 
Table 2. Grams/bush bark yield of cinnamon grown under rubber inter row spacings of $7.2 \mathrm{~m}-18.0 \mathrm{~m}$ in the $4^{\text {th }}, 5^{\text {th }}$, and $6^{\text {th }}$ harvests taken in the $6^{\text {th }}, 7^{\text {th }}$ and $8^{\text {th }}$ years after establishment. The $1^{\text {st }}$ six inter row spacings of $7.2 m-13.2 \mathrm{~m}$ are with single row (s) of rubber while the next five are with paired rows (p) of rubber

\begin{tabular}{|c|c|c|c|c|c|c|c|c|c|c|c|}
\hline & \multicolumn{11}{|c|}{ Bark yicld (g/bush) } \\
\hline Harvest & $7.2 \mathrm{~s}$ & $8.4 \mathrm{~s}$ & $9.6 \mathrm{~s}$ & $10.8 \mathrm{~s}$ & $12.0 \mathrm{~s}$ & $.13 .2 \mathrm{~s}$ & 13.2p & $14.4 p$ & $15.6 \mathrm{p}$ & 16.8p & $18.0 \mathrm{p}$ \\
\hline $4^{\text {th }}$ & $26.3^{G}$ & $28.6^{G}$ & $31.6^{\mathrm{GF}}$ & $31.2^{\mathrm{GF}}$ & $37.3^{\mathrm{EF}}$ & $43.0^{\mathrm{CDE}}$ & $39.0^{\mathrm{DEF}}$ & $47.4^{\mathrm{BCD}}$ & $53.6^{\mathrm{AB}}$ & $56.5^{\lambda}$ & $52.6^{\mathrm{BC}}$ \\
\hline $5^{\text {th }}$ & $22.8^{\mathrm{CD}}$ & $28.9^{\mathrm{D}}$ & $34.3^{\mathrm{BCD}}$ & $33.7^{\mathrm{CD}}$ & $35.4^{\mathrm{BCD}}$ & $42.8^{\mathrm{AB}}$ & $33.6^{\mathrm{CD}}$ & $38.8^{\mathrm{BC}}$ & $43.0^{\mathrm{AB}}$ & $49.3^{A}$ & $.50 .1^{\mathrm{A}}$ \\
\hline $6^{\text {th }}$ & $18.6^{\mathrm{F}}$ & $20.5^{\mathrm{EF}}$ & $27.5^{\mathrm{DE}}$ & $32.6^{\mathrm{C}}$ & $37.5^{\mathrm{BC}}$ & $44.0^{\mathrm{AB}}$ & $32.7^{\mathrm{CD}}$ & $37.0^{\mathrm{BC}}$ & $47.6^{\mathrm{AB}}$ & $51.8^{\wedge}$ & $52.5^{\mathrm{A}}$ \\
\hline
\end{tabular}

Means with the same letter within a harvest do not differ significantly $(p \leq 0.05)$

Table 3. Kg/ha bark yield of cinnamon grown under inter row spacings of $7.2 \mathrm{~m}-18.0 \mathrm{~m}$ of rubber in the $4^{\text {th }}, 5^{\text {th }}$, and $6^{\text {th }}$ harvests taken in the $6^{\text {th }}, 7^{\text {th }}$ and $8^{\text {th }}$ years after establishment. The first six inter row spacings $7.2 m-13.2 m$ are with single row(s) spacings of rubber while the next five are with paired rows $(p)$ of rubber

\begin{tabular}{|c|c|c|c|c|c|c|c|c|c|c|c|}
\hline \multirow[b]{2}{*}{ Harvest } & \multirow[b]{2}{*}{$7.2 \mathrm{~s}$} & \multicolumn{9}{|c|}{ Bark yield (kg/ha) } & \multirow{2}{*}{$18.0 p$} \\
\hline & & $8.4 \mathrm{~s}$ & $9.6 \mathrm{~s}$ & $10.8 \mathrm{~s}$ & $12.0 \mathrm{~s}$ & $13.2 \mathrm{~s}$ & $13.2 \mathrm{p}$ & $14.4 p$ & $15.6 p$ & $16.8 p$ & \\
\hline $4^{\text {th }}$ & 335.0 & 244.5 & 319.3 & 336.7 & 414.8 & 488.8 & 382.2 & 477.7 & 552.2 & 629.6 & $\overline{534.6}$ \\
\hline $5^{\text {th }}$ & 305.7 & 285.3 & 356.7 & 364.0 & 392.9 & 487.9 & 329.3 & 391.9 & 451.5 & 517.7 & 541.1 \\
\hline $6^{\text {th }}$ & 171.7 & 203.8 & 287.0 & 352.6 & 417.0 & 500.2 & 320.5 & 373.7 & 490.4 & 548.1 & 565.9 \\
\hline
\end{tabular}


Cinnamon intercropping under rubber

Total length of harvested sticks per bush

Treatment effects on the total length of sticks harvested/bush was evident and the trend was an increase of the total length with the increase in the inter row spacing with the exception of the $13.2 \mathrm{~m} \mathrm{P}$ treatment. The total length of sticks harvested in a bush was significantly lower in the $7.2 \mathrm{~m} \mathrm{~S}$ and $8.4 \mathrm{~m} \mathrm{~S}$ inter row spacing treatments at all three harvests. Among the paired row systems the total length in the $13.2 \mathrm{~m} \mathrm{P}$ system was lowest but was higher than that of the $13.2 \mathrm{~m} \mathrm{~S}$ treatment. The lengths of sticks produced in $14.4 \mathrm{~m} \mathrm{P}, 15.6 \mathrm{~m} \mathrm{P}, 16.8 \mathrm{~m} \mathrm{P}$ and $18.0 \mathrm{~m} \mathrm{P}$ were higher and significantly greater than those in narrow inter row spacings ranging from $7.2 \mathrm{~m} \mathrm{~S}-12.0 \mathrm{~m} \mathrm{~S}$ treatments in all three harvests (Fig 1).

\section{Average length of shoot}

There were no significant differences in the average length of harvested stick among treatments in the $4^{\text {th }}$ harvest except the $8.4 \mathrm{~m}$ treatment that had the lowest length. In the $5^{\text {th }}$ and $6^{\text {th }}$ harvests both the $7.2 \mathrm{~m}$ and $8.4 \mathrm{~m}$ treatments had significantly lower lengths than all other treatments (Fig 2).

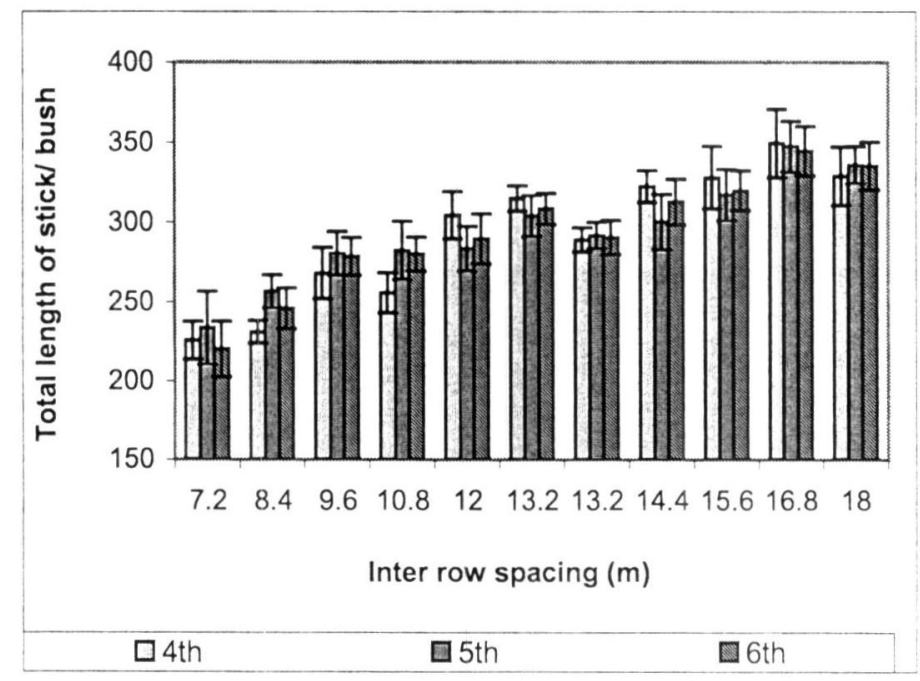

Fig. 1. Effect of inter row spacing of $7.2 \mathrm{~m}-18.0 \mathrm{~m}$ in rubber on the total length of sticks of cinnamon harvested per bush at the $4^{\text {th }}, 5^{\text {th }}$ and $6^{\text {th }}$ harvests. The first six treatments of $7.2 \mathrm{~m}-13.2 \mathrm{~m}$ are with single rows of rubber while the next five treatments with $.13 .2 \mathrm{~m}-18.0 \mathrm{~m}$ are with paired rows of rubber. Each value is a mean of four replicates $\pm \mathrm{SE}$ 


\section{S S Pathiratna et al.}

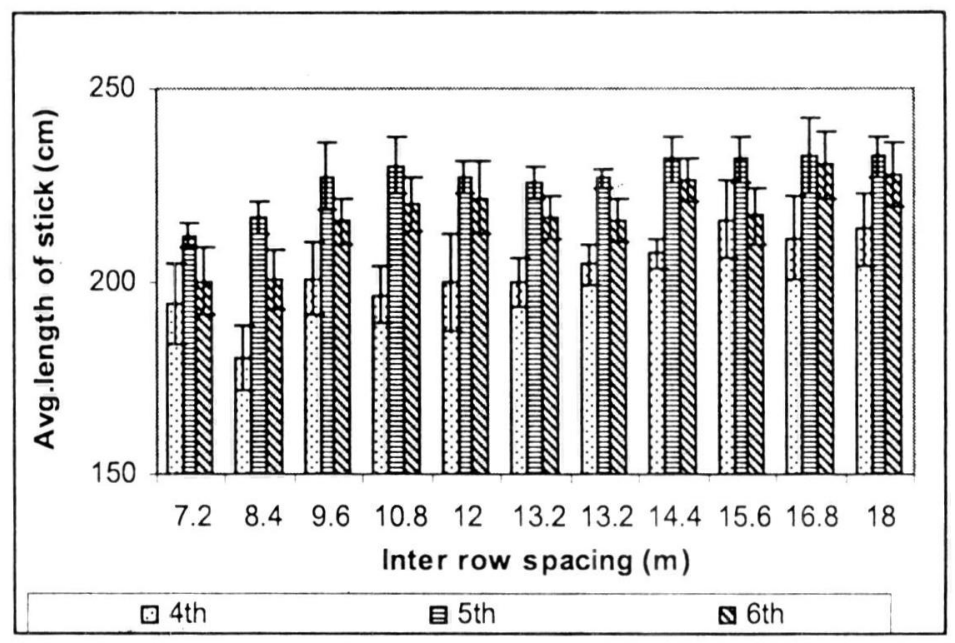

Fig 2. Effect of inter row spacing of $7.2 \mathrm{~m}-18.0 \mathrm{~m}$ in rubber on the average length of cinnamon shoots harvested in the $4^{\text {th }}, 5^{\text {th }}$ and $6^{\text {th }}$ harvests. The first six treatments of $7.2 \mathrm{~m}-13.2 \mathrm{~m}$ are with single rows of rubber while the next five treatments with $13.2 \mathrm{~m}-18.0 \mathrm{~m}$ are with paired rows of rubber. Each value is a mean of four replicates $\pm \mathrm{SE}$

\section{Weight of bark/ $\mathrm{cm}^{2}$}

Bark thickness is an important parameter but is difficult to measure accurately. Instead the weight of bark $/ \mathrm{cm}^{2}$ was determined and was considered as more accurate. The general trend was that this parameter increased with the increase of the inter row space except in the $13.2 \mathrm{~m}$ $\mathrm{P}$ treatment in all the three harvests. In the $4^{\text {th }}$ harvest all single row treatments except the $13.2 \mathrm{~m} \mathrm{~S}$ treatment gave significantly lower weight $/ \mathrm{cm}^{2}$ than paired row treatments. The exception here was the $13.2 \mathrm{~m} \mathrm{P}$ treatment where weight $/ \mathrm{cm}^{2}$ was comparable with the single row treatments. In the $5^{\text {th }}$ and $6^{\text {th }}$ harvests treatments with $7.2 \mathrm{~m} \mathrm{~S}, 8.4 \mathrm{~m} \mathrm{~S}$ and $13.2 \mathrm{~m} \mathrm{P}$ treatments had the lowest weights showing all paired row treatments and the $13.2 \mathrm{~m} \mathrm{~S}$ treatment were comparable except the $13.2 \mathrm{~m} \mathrm{P}$ treatment (Fig 3).

\section{Growth of rubber trees under intercropping}

The effect of rubber spacing on the growth in girth of rubber trees was evident, hence the growth of rubber trees in treatments with the lowest density was significantly greater than in high density treatments. Highest girth of rubber trees was recorded in the $13.2 \mathrm{~m}$ $\mathrm{S}$, the lowest density treatment with 331 trees/ha in all three years. The growth of rubber in all treatments was comparable with the $8.4 \mathrm{~m} \mathrm{~S}$ treatment except with $13.2 \mathrm{~m} \mathrm{~S}$ treatment in both $6^{\text {th }}$ and $7^{\text {th }}$ years. In the $8^{\text {th }}$ year growth in the $8.4 \mathrm{~m}$ $\mathrm{S}$ treatment was comparable with all other treatments (Table 4). 


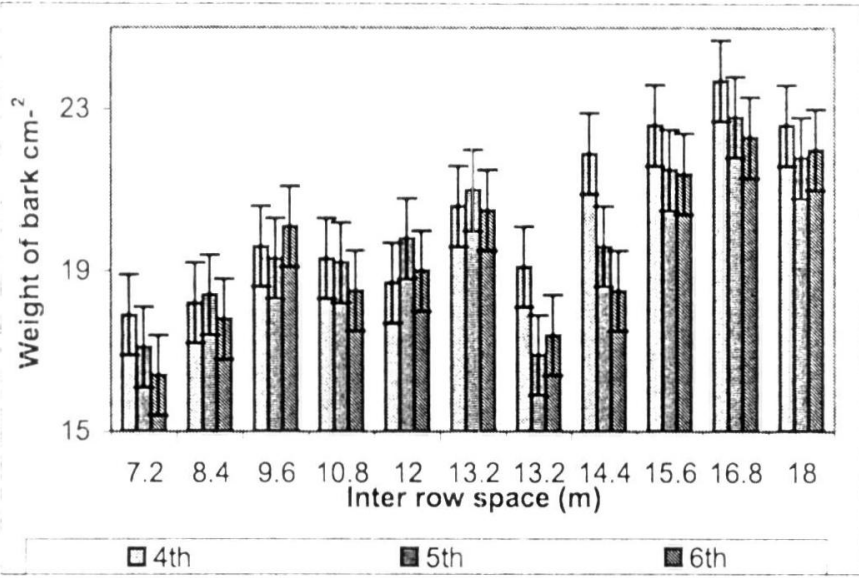

Fig 3. Effect of inter row spacing of $7.2 \mathrm{~m}-18.0 \mathrm{~m}$ of rubber on the weight of bark $/ \mathrm{cm}^{2}$ in cinnamon at the $4^{\text {th }}, 5^{\text {th }}$ and $6^{\text {th }}$ harvests. The first six treatments of $7.2 \mathrm{~m}-13.2 \mathrm{~m}$ are with single rows of rubber while the next five treatments with $13.2 \mathrm{~m}-18.0 \mathrm{~m}$ are with paired rows of rubber. Each value is a mean of four replicates $\pm \mathrm{SE}$

Growth of rubber trees in the absence of the cinnamon intercrop

Growth of rubber trees planted with the same inter row spacings and without cinnamon as intercrop was also measured in the $7^{\text {th }}$ and $8^{\text {th }}$ years. The pattern of growth of these trees was very similar to those trees in the presence of cinnamon as the intercrop. The treatments with $10.8 \mathrm{~m} \mathrm{~S}, 12.0 \mathrm{~m} \mathrm{~S}$ and $13.2 \mathrm{~m} \mathrm{~S}$ treatments had the highest girths in $7^{\text {th }}$ and $8^{\text {th }}$ year. All other treatments including the $8.4 \mathrm{~m} \mathrm{~S}$ treatment had comparable girth in both years (Table 5). The summed mean of girth of trees (both $\mathrm{S}$ and $\mathrm{P}$ treatments) with and without cinnamon as inter crop in the $7^{\text {th }}$ year were $57.1 \mathrm{~cm}$ and $53.4 \mathrm{~cm}$ respectively and were significantly different $(p \leq 0.001)$ and in the $8^{\text {th }}$ year the summed mean for treatments with and without cinnamon was $60.8 \mathrm{~cm}$ and $57.3 \mathrm{~cm}$ respectively and also were significantly different $\quad(\mathrm{p} \leq 0.001)$ showing the growth of rubber was always greater in the presence of cinnamon as intercrop.

\section{Yield of rubber under inter cropping}

Rubber trees were in tapping for two years and the grams/tree/tapping $(\mathrm{g} / \mathrm{t} / \mathrm{t})$ yield of rubber trees just as the growth was highest in the treatments with lowest tree densities viz: $10.8 \mathrm{~m} \mathrm{~S}$, $12.0 \mathrm{~m} \mathrm{~S}$ and $13.2 \mathrm{~m} \mathrm{~S}$ treatments in both years. All paired row treatments had comparable yields in both years of tapping. It is also evident that the yield of $8.4 \mathrm{~m} \mathrm{~S}$ treatment was comparable with all treatments except the $12.0 \mathrm{~m} \mathrm{~S}$ and $13.2 \mathrm{~m} \mathrm{~S}$ in the first year of tapping while in the $2^{\text {nd }}$ year the $8.4 \mathrm{~m} \mathrm{~S}$ treatments was comparable with all treatments except the $10.8 \mathrm{~m} \mathrm{~S}, 12.0 \mathrm{~m} \mathrm{~S}$ and $13.2 \mathrm{~m} \mathrm{~S}$ treatments (Table 6). 
Table 4. Growth of rubber trees in the $6^{\text {th }}-8^{\text {th }}$ years after establishment under different inter row spacings in the presence of cinnamon as inter crop. The first six inter row spacings of $7.2 \mathrm{~m}-13.2 \mathrm{~m}$ are with single rows (s) of rubber and the next five of $13.2 \mathrm{~m}-18.0 \mathrm{~m}$ are with paired rows (p)

\begin{tabular}{|c|c|c|c|c|c|c|c|c|c|c|c|}
\hline \multirow[b]{2}{*}{ Year } & \multicolumn{11}{|c|}{ Growth in girth of rubber trees $(\mathrm{cm})$} \\
\hline & $7.2 \mathrm{~s}$ & $8.4 \mathrm{~s}$ & $9.6 \mathrm{~s}$ & $10.8 \mathrm{~s}$ & $12.0 \mathrm{~s}$ & $13.2 \mathrm{~s}$ & $13.2 \mathrm{p}$ & $14.4 p$ & $15.6 \mathrm{p}$ & $16.8 p$ & $18.0 p$ \\
\hline $6^{\text {th }}$ & $49.9^{\mathrm{D}}$ & $52.8^{\mathrm{BCD}}$ & $52.2^{\mathrm{BCD}}$ & $54.0^{\mathrm{ABC}}$ & $55.2^{\mathrm{AB}}$ & $56.3^{A}$ & $51.9^{\mathrm{ECD}}$ & $50.8^{\mathrm{CD}}$ & $49.9^{5}$ & $49.6^{\mathrm{D}}$ & $51.4^{\mathrm{CD}}$ \\
\hline $7^{\text {th }}$ & $55.2^{\mathrm{C}}$ & $57.0^{\mathrm{BC}}$ & $57.7^{\mathrm{BC}}$ & $58.5^{\mathrm{ABC}}$ & $60.4^{\mathrm{AB}}$ & $61.5^{\mathrm{A}}$ & $56.3^{\mathrm{C}}$ & $55.7^{\mathrm{c}}$ & $55.1^{\mathrm{C}}$ & $54.5^{\mathrm{C}}$ & $55.7^{c}$ \\
\hline $8^{\text {th }}$ & $58.1^{\mathrm{C}}$ & $61.1^{\mathrm{ABC}}$ & $60.8^{\mathrm{ABC}}$ & $62.6^{\mathrm{ABC}}$ & $64.0^{\mathrm{AB}}$ & $65.4^{\mathrm{A}}$ & $59.7^{\mathrm{BC}}$ & $58.7^{\mathrm{BC}}$ & $59.8^{\mathrm{BC}}$ & $58.0^{c}$ & $60.1^{\mathrm{ABC}}$ \\
\hline
\end{tabular}

Values with the same letter within a year do not differ significantly

Table 5. Growth of rubber trees in the $7^{\text {th }}$ and $8^{\text {th }}$ years after establishment under different inter row spacings in the absence of the inter crop. The first six inter row spacings of $7.2 m-13.2 m$ are single rows (s) and $13.2 m-18.0 m$ are paired rows $(p)$ of rubber

\begin{tabular}{|c|c|c|c|c|c|c|c|c|c|c|c|}
\hline \multirow[b]{2}{*}{ Year } & \multicolumn{11}{|c|}{ Growth in girth of rubber trees (cm) } \\
\hline & 7.2 & 8.4 & 9.6 & 10.8 & 12.0 & 13.2 & 13.2 & 14.4 & 15.6 & 16.8 & 18.0 \\
\hline $7^{\text {th }}$ & $53.4^{\mathrm{BC}}$ & $52.8^{\mathrm{BC}}$ & $51.9^{\mathrm{BC}}$ & $54.9^{\mathrm{AB}}$ & $56.9^{A}$ & $56.4^{\mathrm{A}}$ & $53.4^{\mathrm{BC}}$ & $51.6^{\mathrm{BC}}$ & $50.6^{C}$ & $51.5^{c}$ & $52.9^{\mathrm{BC}}$ \\
\hline $8^{\text {th }}$ & $57.8^{\mathrm{BC}}$ & $56.1^{\mathrm{BC}}$ & $56.9^{\mathrm{BC}}$ & $60.9^{\mathrm{AB}}$ & $61.4^{\mathrm{A}}$ & $61.1^{\mathrm{A}}$ & $56.3^{\mathrm{BC}}$ & $54.4^{\mathrm{CD}}$ & $55.5^{\mathrm{C}}$ & $54.9^{\mathrm{CD}}$ & $55.5^{\mathrm{C}}$ \\
\hline
\end{tabular}

Values with the same letter within a year are not significantly different

Table 6. The yield of rubber in $\mathrm{g} / \mathrm{t} / \mathrm{t}$ under different inter row spacing systems inter cropped with cinnamon in the $1^{\text {st }}$ and $2^{\text {nd }}$ years of tapping $\left(7^{\text {th }}\right.$ and $8^{\text {th }}$ years after establishment). First six inter row spacing treatments of $7.2 \mathrm{~m}-13.2 \mathrm{~m}$ are with single rows $(\mathrm{s})$ and the next five treatments with $13.2 m-18.0 m$ are with paired rows $(p)$ of rubber

\begin{tabular}{|c|c|c|c|c|c|c|c|c|c|c|c|}
\hline \multirow{2}{*}{ Year } & \multicolumn{11}{|c|}{ Yicld of rubber trees g/t/t } \\
\hline & $7.2 \mathrm{~s}$ & $8.4 \mathrm{~s}$ & $9.6 \mathrm{~s}$ & $10.8 \mathrm{~s}$ & $12.0 \mathrm{~s}$ & $13.2 \mathrm{~s}$ & $13.2 p$ & $14.4 p$ & $15.6 p$ & $16.8 \mathrm{p}$ & $18.0 p$ \\
\hline $\begin{array}{l}1^{\text {st }} \\
2^{\text {nd }}\end{array}$ & $\begin{array}{l}33.4^{\mathrm{CDE}} \\
31.8^{\mathrm{D}}\end{array}$ & $\begin{array}{l}36.4^{\mathrm{CDE}} \\
33.1^{\mathrm{CD}}\end{array}$ & $\begin{array}{l}38.3^{\mathrm{BCD}} \\
36.5^{\mathrm{BC}}\end{array}$ & $\begin{array}{l}40.2^{\mathrm{ABC}} \\
39.3 \mathrm{~A}^{\mathrm{B}}\end{array}$ & $\begin{array}{l}45.2^{A} \\
43.2^{A}\end{array}$ & $\begin{array}{l}42.6^{\mathrm{AB}} \\
40.1^{\mathrm{AB}}\end{array}$ & $\begin{array}{l}31.2^{\mathrm{DE}} \\
28.9^{\mathrm{D}}\end{array}$ & $\begin{array}{l}31.4^{\mathrm{DE}} \\
29.0^{\mathrm{D}}\end{array}$ & $\begin{array}{l}34.8^{\mathrm{CDE}} \\
30.9^{\mathrm{D}}\end{array}$ & $33 .^{\mathrm{CDE}}$ & $\begin{array}{l}29.6^{\mathrm{E}} \\
30.1^{\mathrm{D}}\end{array}$ \\
\hline
\end{tabular}

Values with the same letter within a year do not differ significantly 


\section{Cinnamon intercropping under rubber}

The highest yields $(\mathrm{kg} / \mathrm{ha})$ in the first year of tapping was obtained in the treatments with the highest tree density i.e. the $7.2 \mathrm{~m} \mathrm{~S}$ treatment and was comparable with other high density treatments viz: $8.4 \mathrm{~m} \mathrm{~S}, 9.6 \mathrm{~m} \mathrm{~S}, 13.2 \mathrm{~m}$ $P$. The yield of other treatments was comparable. In the second year of tapping $7.2 \mathrm{~m} \mathrm{~S}$ and $8.4 \mathrm{~m} \mathrm{~S}$ treatments gave the highest $\mathrm{kg} / \mathrm{ha}$ yield and the yield of the $8.4 \mathrm{~m} \mathrm{~S}$ treatment was also comparable with all other treatments except the $16.8 \mathrm{~m} \mathrm{P}$ and $18.0 \mathrm{~m} \mathrm{P}$ treatments (Table 7).

\section{Yield of rubber without cinnamon inter crop}

The $\mathrm{g} / \mathrm{t} / \mathrm{t}$ yield of these trees was taken only in the $8^{\text {th }}$ year and shows a trend similar to treatments in the presence of intercrops. The highest yields were obtained with $12.0 \mathrm{~m} \mathrm{~S}$ and $13.2 \mathrm{~m} \mathrm{~S}$ treatments. The yield of all other treatments were comparable with $8.4 \mathrm{~m} \mathrm{~S}$ except that of $18.0 \mathrm{~m} \mathrm{P}$ treatment. The lowest yields were in the $18.0 \mathrm{~m} \mathrm{P}$ and $13.2 \mathrm{~m} \mathrm{P}$ treatment (Table $8)$.

There was also a significant $(\mathrm{p} \leq 0.001)$ difference between the mean $\mathrm{g} / \mathrm{t} / \mathrm{t}$ yields of rubber in treatments with and without cinnamon as the intercrop for the $2^{\text {nd }}$ year of tapping and was $33.0 \mathrm{~g}$ and $26.0 \mathrm{~g}$ respectively showing that the yields are always higher in treatments with cinnamon than without.

\section{Light availability in the inter row space}

Light interception by the rubber canopy was greatest in the $7.2 \mathrm{~m} \mathrm{~S}$ and $8.4 \mathrm{~m} \mathrm{~S}$ treatments and also was high in places close to rubber trees $(3.0 \mathrm{~m})$ in all treatments. Light availability was between $70 \%-80 \%$ in the middle of the inter row in all treatments with the inter row space of $10.8 \mathrm{mS}-18.0 \mathrm{P}$. This shows that the canopy has not spread into the inter row far beyond $3.0 \mathrm{~m}-4.0 \mathrm{~m}$ (Fig 4).



Fig 4. Percentage incident light available above the cinnamon canopy (1) $3.0 \mathrm{~m}$ from the rubber trees and (2) in the middle of the inter row space under different inter row spacings measured in the $8^{\text {th }}$ year. Each value is a mean of two replicates $\pm \mathrm{SE}$ 
Table 7. The yield of rubber in $\mathrm{kg} / \mathrm{ha}$ under different inter row spacing systems inter cropped with cinnamon in the $1^{\text {st }}$ and $2^{\text {nd }}$ years of tapping

\begin{tabular}{|c|c|c|c|c|c|c|c|c|c|c|c|}
\hline \multirow[b]{2}{*}{ Year } & \multicolumn{11}{|c|}{ Yield of rubber trees $\mathrm{kg} / \mathrm{ha}$} \\
\hline & $7.2 \mathrm{~s}$ & $8.4 \mathrm{~s}$ & $9.6 \mathrm{~s}$ & $10.8 \mathrm{~s}$ & $12.0 \mathrm{~s}$ & $13.2 \mathrm{~s}$ & $13.2 p$ & $14.4 p$ & $15.6 \mathrm{p}$ & $16.8 p$ & $18.0 p$ \\
\hline $1^{\text {st }}$ & $2705^{A}$ & $2531^{\mathrm{AB}}$ & $2329^{\mathrm{ABC}}$ & $2171^{B C}$ & $2196^{\mathrm{BC}}$ & $1975^{C}$ & $2381^{\mathrm{ABC}}$ & $2133^{B C}$ & $2293^{B C}$ & $2047^{\mathrm{c}}$ & $1989^{C}$ \\
\hline $2^{\text {nd }}$ & $2579^{\mathrm{A}}$ & $2299^{\mathrm{AB}}$ & $2215^{\mathrm{BC}}$ & $2120^{\mathrm{BCD}}$ & $2100^{\mathrm{BCD}}$ & $1859^{\mathrm{BC}}$ & $2207^{\mathrm{BC}}$ & $2090^{B C D}$ & $2036^{\mathrm{BCDE}}$ & $1917^{\mathrm{CDE}}$ & $1749^{\mathrm{E}}$ \\
\hline
\end{tabular}

Values with the same letter within a year do not differ significantly

Table 8. The $\mathrm{g} / \mathrm{t} / \mathrm{t}$ yield of rubber under inter row spacing systems of $7.2 \mathrm{~m} \mathrm{~s}-18.0 \mathrm{~m} p$ without cinnamon inter crop in the $2^{\text {nd }}$ year of tapping

\begin{tabular}{|c|c|c|c|c|c|c|c|c|c|c|c|}
\hline \multirow[b]{2}{*}{ Year } & \multicolumn{11}{|c|}{ Yield of rubber trees $\mathrm{g} / \mathrm{t} / \mathrm{t}$} \\
\hline & $7.2 \mathrm{~s}$ & $8.4 \mathrm{~s}$ & $9.6 \mathrm{~s}$ & $10.8 \mathrm{~s}$ & $12.0 \mathrm{~s}$ & $13.2 \mathrm{~s}$ & $13.2 \mathrm{p}$ & $14.4 p$ & $15.6 p$ & $16.8 p$ & 18.0p \\
\hline $8^{\text {th }}$ & $24.5^{\mathrm{C}}$ & $26.8^{\mathrm{BC}}$ & $26.3^{\mathrm{BC}}$ & $30.0^{B}$ & $31.6^{\mathrm{AB}}$ & $34.9^{A}$ & $21.7^{\mathrm{CD}}$ & $22.6^{\mathrm{C}}$ & $22.3^{C}$ & $24.9^{C}$ & $20.7^{\mathrm{D}}$ \\
\hline
\end{tabular}

Values with the same letter do not differ significantly 


\section{Cinnamon intercropping under rubber}

Cumulative net revenue in the system

Discounted cumulative net revenue of the rubber/cinnamon intercropping systems under all spacings showed a gain at the end of the 8 year period and the largest gains were in the three widest inter row spacing treatments $(15.6 \mathrm{~m} \mathrm{P}, 16.8 \mathrm{~m} \mathrm{P}$ and $18.0 \mathrm{~m} \mathrm{P})$ where rubber tree densities were 471,441 and 415 /ha. followed by the $12.0 \mathrm{~m} \mathrm{~S}$ and $13.2 \mathrm{~m} \mathrm{~S}, 13.2 \mathrm{~m}$ $\mathrm{P}, 14.4 \mathrm{~m} \mathrm{P}$ treatments with tree densities of 347 and 331 trees/ha. In the $12.0 \mathrm{~m} \mathrm{~S}$ and $13.2 \mathrm{~m} \mathrm{~S}$ treatments this is due to the high $\mathrm{kg} / \mathrm{ha}$ rubber yields and high cinnamon yields. In $15.6 \mathrm{~m} \mathrm{P}-18.0 \mathrm{~m} P$ treatments this is due to high cinnamon yields sustained (Fig 5).

An estimate of the discounted cumulative net revenue in the $8.4 \mathrm{~m}$ inter row spacing with a rubber density of density 496 trees/ha without inter crops however showed a deficit of Rs.36974/ha at the end of the 8 year period compared to the same treatment with cinnamon as intercrop giving a gain of Rs.248,000/ha.

\section{Discussion}

This experiment commenced in 1998 and the results obtained during the first five year period on the growth of rubber and the yield of cinnamon in the three harvests were reported earlier (Pathiratna et al., 2004), along with a cash flow analysis (Pathiratna and Edirisinghe, 2004). During this first five year period there has been a decline in cinnamon bark yield in treatments with

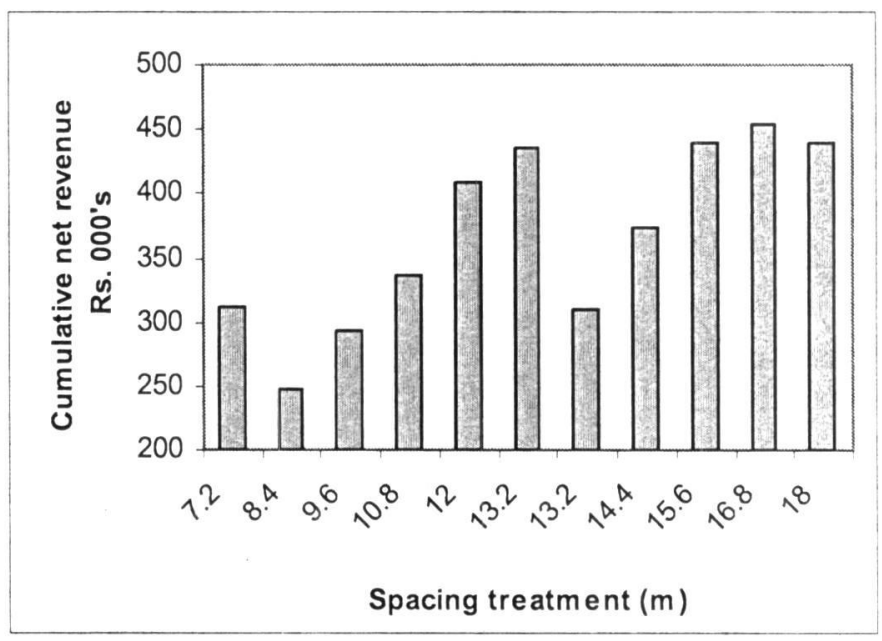

Fig. 5. Cumulative net revenue/ha in rubber/cinnamon inter cropping systems under inter row spacings of $7.2 \mathrm{~m}$ single row $-18.0 \mathrm{~m}$ paired row spacing systems for the eight year period. Cinnamon was first harvested in the $3^{\text {rd }}$ year and rubber first harvested in the $7^{\text {th }}$ year after establishment 


\section{S S Pathiratna et al.}

narrow inter row spacings with the largest decline in treatments with the smallest inter row space, mainly due to competition from rubber. The effect of competition from rubber was clearly seen in rows close to the rubber rows and has resulted in a reduction in the weight of bark $/ \mathrm{cm}^{2}$ and a reduction in the total length of harvested sticks/bush. But a decline in the length /stick was not seen. One reason for this was that under shade the length of individual sticks have increased due to etiolating effects (Ballare et al., 1995) but there was a reduction in the number of sticks per bush.

This trend present in the first five years seems to have continued in the next three harvests reported here. Further reductions in the available light in treatments with narrow inter row spacings of $7.2 \mathrm{~m} \mathrm{~S}$ and $8.4 \mathrm{~m} \mathrm{~S}$ and also in cinnamon rows close to rubber trees were seen. It is also evident that the light levels in the middle of the inter row space have remained high to sustain good cinnamon bark yields in treatments with wider inter row spacings ranging from $10.8 \mathrm{~m} \mathrm{~S}$ to $18.0 \mathrm{~m} \mathrm{P}$. Further reductions in the overall growth and in g/bush cinnamon bark yields in the treatments with narrow inter row spacings particularly in the $7.2 \mathrm{~m} \mathrm{~S}$ and $8.4 \mathrm{~m} \mathrm{~S}$ treatments were seen due to the severe reduction in light and competition from rubber roots combined with the growth retarding effect due to continuous harvesting. Annual defoliation at harvests can have severe effects on the dry matter production (Kandiah et al., 1984) and could have reduced the growth and bark yield of cinnamon (Pathiratna and Perera, 2004). Under such conditions all yield components of cinnamon (Pathiratna, 2006a) seems to be affected. This is clearly seen in the $6^{\text {th }}$ harvest where the yield and yield components viz: length of sticks/bush and weight of bark $/ \mathrm{cm}^{2}$ were lowest. The elongation of sticks was mainly due to the etiolating effects due to mutual shading even under moderate shade levels (Pathiratna and Perera 2006) and this is seen in all inter row spacing treatments except in those with narrow inter row spacings where light levels were very low.

In other treatments mostly those above $10.8 \mathrm{~m}$ where light levels remained moderate, cumulative bark yields were not greatly affected and the effects on yield components were less. It is also evident that in treatments with high tree densities as in the $13.2 \mathrm{~m} \mathrm{P}$ treatment where it was 545 trees/ha compared to 331 in $13.2 \mathrm{~m} \mathrm{~S}$, the retarding effects on cinnamon yield as well as on the growth and yield of rubber were high (Tables 2,4 and 6). This was so even without cinnamon as the intercrop (Tables 5 and 8). This is an indication that it is the root competition in this $13.2 \mathrm{~m} \mathrm{P}$ treatment that has been effective in reducing cinnamon yields and also there has been more competition between rubber trees in this 
Cinnamon intercropping under rubber

treatment because in both $13.2 \mathrm{~m}$ treatments light availability was similar.

The greater growth and $\mathrm{g} / \mathrm{t} / \mathrm{t}$ yield of rubber in wider inter row spacing treatments was directly due to the reduced rubber tree density and there was no apparent effect of intercrops on the growth or yield of rubber. However, the straight relationship seen between growth and $\mathrm{g} / \mathrm{t} / \mathrm{t}$ yield with rubber tree density in single row treatments was not exactly so in paired rows.

It is also evident that the growth and yield of rubber was significantly greater in the presence of intercrops than in their absence and is partly due to the possible advantage of the fertilizer added for the intercrop (Zainol et al., 1993) and other management practices.

The net revenue in the $8.4 \mathrm{~m}$ treatment without cinnamon in this experiment shows a deficit of Rs.36947/ha compared to a gain of 248,000 /ha in the same treatment with cinnamon as intercrop. Intercropping under all other spacing systems also showed gains, the highest being in the $16.8 \mathrm{~m}$ treatment that showed a net gain of Rs. $455,00 / \mathrm{ha}$ at the end of the $8^{\text {th }}$ year. This shows a clear advantage of intercropping cinnamon as the pay back period for mono crop rubber was estimated to be eleven years (Edirisinghe, 2004). The high cumulative net revenue in wider inter row spacing treatments was due to both reduced cost on rubber and the high income from cinnamon. The higher $\mathrm{kg} / \mathrm{ha}$ rubber yields in the high density treatments were due to high number of trees but is not represented in accumulated revenue due to high cost of upkeep and tapping of rubber (Pathiratna et al., 2006) and low cinnamon yields in these treatments.

The benefits of having cinnamon as an intercrop on the growth and yield of rubber, the possibility of using wider inter row spacings for sustainable rubber/cinnamon intercropping systems and the high economic gains possible under such systems are evident in these results.

\section{Acknowledgements}

The assistance of Mrs Wasana Wijesuriya, the Biometrician and $\mathrm{Mr}$ Keminda Herath the Assistant Biometrician in analysing the data is greatly appreciated.

\section{References}

Ballare, C L, Scopel, C L, Sanchez, R A (1995). Plant photomorphogenesis in canopies, crop growth and yield. Hort Science 30 (6), 1172-1181.

Cannell, M G R (1983). Plant population and yield of tree and herbaceous crops. In: Plant Research and Agroforestry, pp. 455-502. (Ed. P A Huxley) ICRAF Nairobi.

Connor, D J (1983). Plant stress factors and their influence on production of agroforestry plant associations. In: Plant Research in Agroforestry, pp.405-425. (Ed. P A Huxley) ICRAF Nairobi.

Edirisinghe, J C (2004). Estimates for cost of production of rubber (unpublished data). 
L S S Pathiratna et al.

Kandiah, S, Wettasinghe, D $\mathrm{T}$ and Wadasinghe, A (1984). Root influences on shoot development in tea (Camellia sinensis) (L) O Kuntze following shoot pruning. Journal of Horticultural Science 59, 581-587.

Pathiratna, L S S and Perera, M K P (1998). The effect of shade on the bark yield components of cinnamon (Cinnamomum verum J Pres.) intercropped with rubber (Hevea brasiliensis Muell. Arg.) Journal of Plantation Crops 26 (1), 58-62.

Pathiratna, L S S, Nugawela, A and Samarasekera, R K (1998). Shade effects on photosynthesis of cinnamon (Cinnamomum verum J. Pres). Journal of the Rubber Research Institute of Sri Lanka 81, 29-37.

Pathiratna, L S S and Perera, M K P (2002). Contour and east west row planting systems of nubber (Hevea) for inter cropping. 1. Effects ; on growth and yield of component crops. Journal of the Rubber Research Institute of Sri Lanka 85, 53-61.

Pathiratna, L S S and Perera, M K P (2003 a). Contour and east west row planting systems of rubber (Hevea) for inter cropping. 11. Distribution of fine roots in the inter row space. Journal of the Rubber Research Institute of Sri Lanka 86, 1-10.

Pathiratna, L S S and Perera, M K P (2003 b). Contour and east west row planting systems of rubber (Hevea) for inter cropping. 1ll. Light availability in the inter row space. Journal of the Rubber Research Institute of Sri Lanka 86, 1122.

Pathiratna, L S S and Edirisinghe, J C, (2003) Agronomic and economic viability of rubber (Hevea brasiliensis Muell. Arg.)/cinnamon (Cinnamomum verum $\mathrm{J}$ Pres.) intercropping systems involving wider inter row spacings in rubber plantings. Journal of the Rubber Research Institute of Sri Lanka 86, 4657.

Pathiratna, L S S, Perera, M K P and Wijesuriya, B W (2004). Performance of cinnamon (Cinnamomum verum J. Pres.) intercropped at different spacings of rubber (Hevea brasiliensis Muell. Arg.). Natural Rubber Research 17 (2), 150-158.

Pathiratna, L S S and Perera, M K P (2005). Rubber (Hevea basiliensis Muell.Arg.) cinnamon (Cinnamomum verum $J$. Pres) intercropping system: Performance under standard inter row spacings of rubber. Natural Rubber Research 18 (2), 105-113.

Pathiratna, L S S and Perera M K P (2006). Effect of plant density on bark yield of cinnamon intercropped under mature rubber. Agroforestry Systems 68, 123131.

Pathiratna, L S S (2006). A new systematic experimental design for tree crop research. Bulletin of the Rubber Research Institute of Sri Lanka 47, 4043.

Pathiratna, L S S (2007). Factors affecting bark yield components of Cinnamon. Bulletin of the Rubber Research Institute of Sri Lanka 48, 43-48.

Pathiratna, I S S, Seneviratna, P, Waidyanatha, U $P$ De $S$, Samaranayake, A C I, (2006). Effect of tree density on growth, yield and profitability of rubber (Hevea brasiliensis Muell.Arg.) in plantations. Ceylon Journal of Science (Bio Sci) 35 (2) 141-148.

Schroth, G (1999). A review of below ground inter actions in agroforestry focusing on mechanisms and management options. Agroforestry Systems 43, 5-34. 


\section{Cinnamon intercropping under rubber}

van Noordwijk, $\mathrm{M}$ and Purnomoshidi, $\mathrm{P}$ (1995). Root architecture in relation to tree-soil-crop interactions and shoot pruning in agroforestry. Agroforestry Systems 30, 161-173.
Address for correspondence: $\mathrm{Mr} \mathrm{L} \mathrm{S} \mathrm{S}$ Pathiratna, Kurunduwatta Centre Road, Nagoda, Kalutara, Sri Lanka.

E-mail:Isspathi@sinet.lk 